\title{
Arte e educação contra o fetichismo generalizado na sociabilidade contemporânea
}

Newton Duarte*

\section{Resumo}

O artigo desenvolve uma reflexão filosófica sobre a contribuição que a arte e a Educação podem dar ao processo de superação do fetichismo generalizado na sociabilidade contemporânea. No primeiro item, é retomada a tese de Marx segundo a qual a sociabilidade na sociedade capitalista se caracteriza pela universalidade do valor de troca como mediação nas relações sociais. $\mathrm{O}$ artigo defende a posiçáo de que a sociabilidade contemporânea, em que pesem suas diferenças em relação ao século XIX, não só não superou a universalidade do valor de troca como, ao contrário, aprofundou-a, tornando o fetichismo um fenômeno social que abarca todas as dimensões da vida humana na atualidade. No segundo item, o artigo apoia-se nas análises feitas por Vigotski e por Lukács das relaçôes entre os indivíduos e as obras de arte para defender a tese de que a educação escolar deve ter como meta permanente a superação das formas alienadas de consciência que prevalecem na vida cotidiana da sociedade capitalista deste início de século XXI.

Palavras-chave: Arte e educação. Fetichismo. Sociabilidade. Alienação.

* Doutor em Educação pela Unicamp. Professor Titular do Departamento de Psicologia da Educação, Faculdade de Ciências e Letras, Universidade Estadual Paulista Julio de Mesquita -Unesp, campus de Araraquara - SP. 


\section{Introdução}

O tema ${ }^{1}$ proposto para esta sessão especial é Educação e estética na (nova) sociabilidade. Visando a contribuir para a discussão sobre esse tema, defini como título de minha apresentação Arte e educação contra o fetichismo generalizado na sociabilidade contemporânea.

Inicio minhas consideraçóes pela problematização de um aspecto do tema proposto para essa sessão especial. Existiria realmente uma nova sociabilidade? Se existir uma nova sociabilidade, o que a diferenciaria da anterior?

\section{A sociabilidade fetichista da sociedade contemporânea}

Para responder às perguntas formuladas na introdução deste artigo, é necessário primeiramente caracterizar o que define a sociabilidade. Mesmo correndo o risco de dizer o óbvio, entendo que sociabilidade não pode ser outra coisa senão o caráter fundamentalmente social de todo ser humano. Dizer que o ser humano é social significa afirmar que ele pertence a uma determinada sociedade, que sua individualidade é constituída pelas relações sociais das quais participa: "[...] a efetiva riqueza espiritual do indivíduo depende inteiramente da riqueza de suas relaçóes reais" (MARX; ENGELS, 2007 , p. 41). Relações sociais são relações entre os seres humanos dentro de um determinado tipo de sociedade. As principais relaçóes em nossa sociedade são aquelas entre as duas classes sociais fundamentais: de um lado, a classe que detém a propriedade dos meios de produção, isto é, do capital, e de outro, a classe que tem que vender sua força de trabalho para poder viver.

Vivemos em uma sociedade capitalista marcada pela propriedade privada dos meios de produção, pela contradição entre o capital e o trabalho, e pela contradição entre as relações de produção e o desenvolvimento das forças produtivas. Assim era no século XIX, quando Marx analisou a essência da sociedade comandada pela lógica do capital, e assim continua a ser neste início de século XXI. Em que pesem as diferenças entre a vida cotidiana nos dias atuais e no tempo de Marx, o fato é que a essência da sociabilidade na sociedade burguesa não se alterou. Por essa razão, não concordo com a ideia de que exista uma nova sociabilidade ou que estejamos vivendo numa 
sociedade pós-moderna ou numa sociedade do conhecimento. Nós ainda vivemos numa sociedade capitalista.

Ao analisar o dinheiro como relação social, Marx (1987, p. 84) esclarece o que é essencial à sociabilidade na sociedade capitalista:

A dependência mútua e generalizada dos indivíduos reciprocamente indiferentes constitui seu nexo social. Este nexo social se expressa no valor de troca e somente neste a atividade própria ou o produto se transformam para cada indivíduo em uma atividade ou em um produto para ele mesmo. $\mathrm{O}$ indivíduo deve produzir um produto universal: o valor de troca ou, considerado este em si mesmo isoladamente e individualizado, o dinheiro. Por outra parte, o poder que cada indivíduo exerce sobre a atividade dos outros ou sobre as riquezas sociais, ele o possui na medida em que é proprietário de valores de troca, de dinheiro. Seu poder social, assim como seu nexo com a sociedade, ele leva consigo em seu bolso.

$\mathrm{Na}$ sociedade capitalista, o dinheiro é o representante universal da riqueza material e não material e, por essa razão, é a mediação universal nas relaçōes entre os indivíduos. Qualquer abordagem sobre a sociabilidade contemporânea que ignore ou secundarize esse fato estará condenada a permanecer na superfície, nas aparências e nas contingências.

O fato de a mediação decisiva na sociabilidade capitalista ser o dinheiro tem seu correlato na universalização do fetichismo nas relações entre os indivíduos e a realidade social.

O caráter social da atividade, assim como a forma social do produto e a participaçáo do indivíduo na produção, apresentam-se aqui como algo alienado, coisificado frente aos indivíduos, não como sua condição de relacionamento recíproco, mas sim como sua subordinação a relaçóes que subsistem independentemente deles e nascem do choque dos indivíduos reciprocamente indiferentes. [...] No valor de troca o vínculo social entre as pessoas se transforma em relação social entre coisas, a capacidade pessoal em uma capacidade das coisas. (MARX, 1987, p. 84-85). 
Marx viria posteriormente a chamar esse fenômeno de fetichismo da mercadoria:

[...] para encontrar uma analogia temos de nos deslocar à regiáo nebulosa do mundo da religiáo. Aqui, os produtos do cérebro humano parecem dotados de vida própria, figuras autônomas, que mantêm relaçôes entre si e com os homens. Assim, no mundo das mercadorias, acontece com os produtos da mão humana. Isso eu chamo o fetichismo que adere aos produtos aos produtos do trabalho, tâo logo são produzidos como mercadorias, e que, por isso, é inseparável de mercadorias. Esse caráter fetichista do mundo das mercadorias provém, como a análise precedente já demonstrou, do caráter social peculiar do trabalho que produz mercadorias. (MARX, 1983, p. 71).

O caráter fetichista da consciência cotidiana em nossa sociedade decorre, portanto, do fato de que a atividade humana fundamental, que é o trabalho, assume a forma peculiar de atividade produtora de mercadorias. Somente com a superação desse modo de produção e a construção de outro modo de produção, o dos produtores livremente associados, ou seja, o modo de produção comunista, é que as relaçóes sociais perderão a opacidade que as caracteriza na sociedade burguesa e, por consequência, a consciência cotidiana não mais precisará das diversas formas de ilusão que, na atualidade, formam o inevitável complemento ideológico da alienação do trabalho. Marx (1983, p. 76) expressou essa ideia por meio da análise do que será necessário para a superação da religião:

O reflexo religioso do mundo real somente pode desaparecer quando as circunstâncias cotidianas, da vida prática, representarem para os homens relações transparentes e racionais entre si e com a natureza. A figura do processo social da vida, isto é, do processo da produçáo material, apenas se desprenderá do seu místico véu nebuloso quando, como produto de homens livremente socializados ela ficar sob seu controle consciente e planejado. 
Nessa perspectiva, a crítica ao fetichismo teria alguma relevância no processo de superação da sociedade capitalista? Essa crítica corre o risco de cair no idealismo se não tiver sempre presente que "[...] não é a consciência que determina a vida, mas a vida que determina a consciência” (MARX E ENGELS, 2007, p. 94). Mas a crítica ao fetichismo pode ter um papel importante no processo de transformação da sociedade à medida que produza nos indivíduos a consciência da necessidade de transformação das condiçóes sociais objetivas que produzem o fenômeno do fetichismo. É nessa direção que, no próximo item deste artigo, defenderei que a arte e a educação podem contribuir para a luta pela superação da sociabilidade fetichista.

\section{Arte e educação na luta contra o fetichismo}

As consideraçóes que aqui apresentarei se apoiam em estudos que venho realizando numa pesquisa intitulada $O$ tema da formação humana nas análises realizadas por Lukács e por Vigotski das relaçôes entre o individuo e a obra de arte. ${ }^{2}$

Os objetivos dessa pesquisa são:

- analisar os estudos desenvolvidos por Lukács no campo da estética e da crítica literária, buscando detectar as concepçôes do filósofo húngaro acerca do papel da arte na formação do ser humano;

- analisar trabalhos de Vigotski que abordem os efeitos das obras de arte na formação do psiquismo humano;

- analisar as possíveis aproximaçóes e distanciamentos entre Lukács e Vigotski no que se refere ao papel formativo da arte;

- extrair, das análises definidas nos objetivos precedentes, contribuições para a teoria educacional no que se refere às relaçôes entre a formação dos indivíduos e as objetivações do gênero humano.

Tanto na perspectiva lukacsiana como na vigotskiana, as relaçóes entre o objetivo e o subjetivo são abordadas por meio da dialética entre os processos de objetivação e apropriação da cultura material e não material, desde os utensílios e a linguagem na vida cotidiana, até a ciência, a arte e a filosofia. Essa perspectiva pode ser sintetizada na famosa afirmação de MARX (2004, p. 110): "[...] a formação dos cinco sentidos é um trabalho de toda a história do mundo até aqui”. 
No campo da psicologia, Vigotski analisou a arte como uma técnica criada pelo ser humano para dar uma existência social objetiva aos sentimentos, possibilitando assim que os indivíduos se relacionem com esses sentimentos como um objeto, como algo externo que se interioriza por meio da catarse ${ }^{3}$ :

O social existe até mesmo onde há apenas um homem e as suas emoçóes individuais. Por isso, quando a arte realiza a catarse e arrasta para esse fogo purificador as comoçóes mais íntimas e mais vitalmente importantes de uma alma individual, o seu efeito é um efeito social. A questão não se dá da maneira como representa a teoria do contágio, segundo a qual o sentimento que nasce em um indivíduo contagia a todos, torna-se social; ocorre exatamente o contrário. A refundição das emoçôes fora de nós realiza-se por força de um sentimento que foi objetivado, levado para fora de nós, materializado e fixado nos objetos externos da arte, que se tornaram instrumento da sociedade. A peculiaridade essencialíssima do homem, diferentemente do animal, consiste em que ele introduz e separa de seu corpo tanto o dispositivo da técnica quanto o dispositivo do conhecimento científico, que se tornaram instrumentos da sociedade. De igual maneira, a arte é uma técnica social do sentimento, um instrumento da sociedade através do qual incorpora ao ciclo da vida social os aspectos mais íntimos e pessoais do nosso ser. Seria mais correto dizer que o sentimento náo se torna social, mas, ao contrário, torna-se pessoal, quando cada um de nós vivencia uma obra de arte, converte-se em pessoal sem com isto deixar de continuar social. (VIGOTSKI, 1998, p. 315).

A categoria de catarse é também empregada por Lukács (1972, p. 491-525) para análise das relaçóes entre o sujeito e o objeto no processo de recepção da obra de arte pelo indivíduo. Lukács entende que a catarse não é uma categoria puramente estética, sua origem está na vida dos seres humanos. A obra de arte reelabora os conteúdos extraídos da vida, dando-lhes uma configuraçáo que supera o imediatismo e o pragmatismo da cotidianidade. 
A obra de arte é mediadora entre o indivíduo e a vida. É interessante notar que, justamente quando está analisando a catarse como categoria geral da estética, Lukács (1972) menciona um texto seu que tem por objeto a obra Poema pedagógico, de Anton Makarenko:

Como em todas as categorias importantes da estética, também na catarse se comprova que sua origem primária está na vida e não na arte à qual chegou a partir daquela. Como a catarse foi e é um momento constante e significativo da vida social, seu reflexo tem que ser forçosamente um motivo sempre recolhido pela conformação estética e, ademais, um elemento já presente entre as forças formadoras da reconfiguração estética da realidade. Em meu ensaio sobre Makarenko descrevi detalhadamente essa inter-relação entre o fato da vida, a reconfiguração e a aplicação consciente à vida, referindo-me à doutrina pedagógica desse autor. Ali tentei também mostrar que ainda que o fenômeno da catarse mostre já na vida certa afinidade com o trágico, razáo pela qual se objetiva esteticamente do modo mais rico nesse domínio, abarca, entretanto, por seu conteúdo, outro domínio muito mais amplo. Postos agora ante a questão de se essa formulação permite ainda uma generalização ulterior, retomaremos nossas consideraçóes anteriores sobre o caráter desfetichizador do estético e, em relação com elas, seu conteúdo positivo: toda arte, todo efeito artístico, contém uma evocação do núcleo vital humano - o que formula a cada receptor a pergunta goethiana de se ele é núcleo ou casca - e ao mesmo tempo, inseparavelmente dela, uma crítica da vida (da sociedade, da relação que ela produz com a natureza). (LUKÁCS, 1972, p. 500-501).

Nessa passagem, Lukács atribui à doutrina pedagógica de Makarenko um papel similar ao da obra de arte. Assim como o artista, ao produzir a obra de arte, apropria-se dos processos realmente existentes na vida dos seres humanos, inserindo-os numa nova configuração, a da obra de arte como uma totalidade, também a doutrina pedagógica de Makarenko seria, na 
avaliação de Lukács, uma reconfiguração dos fatos vividos pelo educador soviético, sendo o papel dessa reconfiguração o de fazer o próprio educador compreender sua experiência pedagógica numa perspectiva mais ampla, a da construção de uma pedagogia socialista.

Como pesquisador em Educação, não pretendo incorrer na identificação da teorização pedagógica à psicologia vigotskiana da arte ou à teorização filosófica lukacsiana acerca da peculiaridade do estético. A educação escolar é uma prática social cuja especificidade requer uma teorização própria. Tendo esse cuidado, trabalho na pesquisa que dá base a este artigo com a hipótese de que a dialética entre o indivíduo e a obra de arte pode ser uma importante fonte de informaçóes sobre o tema mais amplo da dialética entre a formação do indivíduo e a riqueza não material. Essa hipótese decorre de uma tese que tenho defendido, a de que a questáo central da pedagogia não reside nas relaçóes entre professor e aluno ou dos alunos uns com os outros, mas sim nas relaçóes que professor e alunos estabelecem com os produtos intelectuais da prática social humana em sua totalidade.

Lukács (1972) parte da análise marxiana do fenômeno do fetichismo da mercadoria e defende que a arte teria uma missão desfetichizadora: "[... a tomada de posição em relação ao fetichismo - reconhecido ou não este como tal - constitui-se na linha divisória entre a arte progressista e a reacionária” (LUKÁCS, 1972, p. 381).

Lukács defende a tese de que quase todo grande artista dos séculos XIX e XX se deparou de alguma forma com o problema do fetichismo. Menciona Balzac e Tolstoi como grandes exemplos dessa luta pela representação do mundo humano como obra dos próprios seres humanos, dessa luta pela imanência da realidade humana. Mas Lukács também afirma que existe a pseudoarte, marcadamente no caso da arte burguesa decadente do período imperialista da sociedade capitalista e, nesse caso, a pseudoarte capitula perante o fetichismo, e sua representação da realidade humana permanece na superficialidade da vida cotidiana alienada.

O reflexo estético cria, por um lado, reproduçôes da realidade nas quais o ser em-si da objetividade é transformado em um ser para-nós do mundo representado na individualidade da obra de arte; por outro lado, na eficácia exercida por tais obras, 
desperta e se eleva a autoconsciência humana; quando o sujeito receptivo experimenta - da maneira acima referida - uma tal realidade em si, nasce nele um parasi do sujeito, uma autoconsciência, a qual não está separada de maneira hostil do mundo exterior, mas antes significa uma relação mais rica e mais profunda de um mundo externo concebido com riqueza e profundidade, ao homem enquanto membro da sociedade, da classe, da naçáo, enquanto microcosmos autoconsciente no macrocosmos do desenvolvimento da humanidade. (LUKÁCS, 1970, p. 274-275).

Uma obra de arte produzida em sociedades do passado gera em nós essa autoconsciência, porque a relação entre seu conteúdo e sua forma nos leva a viver os conflitos humanos representados na obra artística como nossos conflitos. A obra de arte opera, nessa relação entre conteúdo e forma, uma crítica à vida, leva o sujeito, no processo de fruição, a uma intensificação daquilo que em sua própria cotidianidade ele vive de forma muitas vezes fetichista e superficial.

A obra de arte caracteriza-se por uma unidade dialética entre a singularidade e a universalidade, entre a objetividade e a subjetividade, entre a total absorção da subjetividade pela riqueza concreta de um momento específico e o significado desse momento para a autoconsciência do gênero humano. Mas como seria isso possível, considerando-se que o reflexo estético da realidade é um processo mimético? O próprio Lukács (1972, p. 264) assim formula essa questão:

[...] a grande maioria das obras de arte reflete imediatamente as relaçóes e estruturas dos homens que influem diretamente em seu destino nas sociedades existentes em cada caso. A personalidade de cada homem delineado pela arte, o modo essencial de cada sentimento que alcança a expressão artística, está atado, com os fios da vida verdadeiramente vivida, a esse terreno imediato de toda a existência humana. Ao recordar novamente o caráter não utópico da mimese estética apresenta-se com toda razão a pergunta: e onde existe aqui campo para o delineamento dos problemas do gênero humano? 
Para compreender corretamente a dialética que rege essas questóes há de se pensar nas relaçóes humanas imediatamente dadas, desde a família até a classe e nação, em seu modo de manifestação por meio das e através das paixóes individuais de personalidades concretas.

A subjetividade dos indivíduos é construída por meio da apropriação das forças sociais objetivamente existentes, inclusive dos conflitos existentes entre essas forças, que impulsionam os conflitos vivenciados subjetivamente pelos indivíduos. Assim como existe nas forças sociais objetivas o conflito entre a tendência ao cerceamento da realidade às singularidades do aquie-agora e a tendência ao desenvolvimento da realidade no sentido da objetivação universal do gênero humano, também o indivíduo vivencia esse conflito, na medida em que as situaçóes singulares das quais ele faz parte contêm objetiva e subjetivamente as contradiçôes que podem conduzir tanto à autoconsciência do gênero humano quanto à absorção da consciência pela superficialidade fetichista da realidade imediata.

Aqui se pode estabelecer uma relação com a educação escolar. O trabalho educativo realiza uma mediação entre a espontaneidade da vivência cotidiana do pertencimento do indivíduo ao gênero humano e a elevação da vida individual a uma relação consciente com o processo histórico de objetivação do gênero humano. $O$ trabalho educativo que não se reduza ao nível da inserção do indivíduo na sociabilidade em-si, mas que tenha por objetivo fundamental o desenvolvimento do indivíduo no sentido da sociabilidade para-si, não terá como valores norteadores aqueles determinados pelas relações sociais fetichizadas, mas sim aqueles valores que, surgidos nas contradiçóes da realidade social, apontem para a superação do fetichismo.

Se a arte propiciar aos indivíduos uma vivência subjetiva intensificada de conflitos que impulsionem a autoconsciência a níveis cada vez mais elevados, ela desempenhará uma função formadora, isto é, educativa.

Por sua vez, o trabalho educativo, seja com a arte, seja com outros conteúdos, tem a mesma meta, pois, se entendermos a educação como um processo pelo qual os seres humanos formam conscientemente outros seres humanos, esse processo só pode se realizar em sua plenitude se lutar contra o fetichismo na medida em o fetichismo é a própria negação do ser humano como criador de sua realidade e de si mesmo. Se a arte tem uma missão 
desfetichizadora, o mesmo acontece com a educação que não capitule perante o fetichismo generalizado na sociabilidade contemporânea.

Para argumentar em favor dessa perspectiva, retomarei a questão da catarse em Lukács. A análise lukacsiana da catarse na recepção da obra de arte é parte de uma teoria mais ampla, na qual, como já foi aqui abordado, a arte possui a função social de produzir a desfetichização da realidade social e de fazer o receptor da obra artística deparar-se com o questionamento acerca do próprio núcleo humano de sua individualidade. A realidade expressa na obra de arte é, para Lukács, sempre a realidade humana, é sempre o mundo dos homens o objeto por excelência da arte. Mais do que isso, Lukács (1989, p. 213) afirma que "[...] toda boa arte e toda boa literatura também é humanista na medida em que não apenas estuda apaixonadamente o homem, a verdadeira essência de sua constituição humana, mas também que, ao mesmo tempo, defende apaixonadamente a integridade humana do homem".

Essa maneira como Lukács (1989) entendia o humanismo da arte explica sua defesa intransigente do realismo, que não pode ser confundido com o naturalismo, o qual não consegue trabalhar artisticamente com a dialética entre essência e aparência e acaba se tornando prisioneiro do fetichismo das formas alienadas que assume a vida cotidiana na sociedade produtora de mercadorias. Enquanto o naturalismo ficaria prisioneiro dos detalhes de uma dada situação, o realismo captaria de forma artisticamente rica os processos e as tendências do movimento da história. Nesse sentido, Lukács concorda com Engels, quando este afirma “[...] o realismo, para mim, implica, para além da verdade do pormenor, a produção verdadeira de personagens típicos em circunstâncias típicas" (MARX; ENGELS, 1986, p. 70). Na criação de uma obra realista, o artista pode ir muito além de suas próprias convicçóes político-ideológicas, e, como exemplo disso, Engels faz referência a Balzac, com sua obra Comédia humana, na qual a derrota da sociedade feudal e da aristocracia é retratada por Balzac de forma muito rica, a ponto de Engels afirmar que, com essa obra de Balzac, ele aprendera "[...] mais do que com todos os historiadores, economistas e estatísticos profissionais do período” (MARX; ENGELS, 1986, p. 71). O conservadorismo político de Balzac foi superado pelo realismo de sua obra artística. Da mesma forma, a posição política socialista de um romancista não implicava, para Engels, que o escritor devesse fazer de seu trabalho 
artístico apenas um pretexto para explicitar suas posiçóes políticas. Não se trata de defender a neutralidade política do artista ou da arte, mas sim de que o valor de uma obra de arte depende da profundidade com que ela capte a contraditória realidade humana, e não de uma tradução direta das convicçôes políticas do artista:

Um romance de inspiração socialista consegue totalmente seu objetivo, na minha opiniáo, se descrever conscientemente as verdadeiras relaçôes mútuas, destruir ilusóes convencionais acerca delas, abalar o otimismo do mundo burguês e levantar dúvidas quanto à natureza eterna da ordem existente, ainda que o autor não ofereça qualquer solução definitiva nem se situe abertamente em qualquer lado definido. (MARX; ENGELS, 1986, p. 73).

Lukács (1989) afirma que o princípio artístico do realismo não está em conflito com o valor da fantasia nem implica qualquer diminuição da importância da subjetividade do artista na criação da obra de arte. O trabalho criativo do artista é tấo mais valorizado quanto mais se compreenda que a obra de arte trabalha com a unidade dialética entre essência e aparência.

Nesse contexto teórico, o conceito de catarse assume grande importância, pois a catarse pode ser entendida como um processo no qual se revela o êxito do efeito do realismo da obra de arte sobre o indivíduo receptor. A catarse é o processo pelo qual o indivíduo receptor é colocado esteticamente em confronto com a essência da realidade, por meio da superação, ainda que momentânea, da heterogeneidade extensiva e superficial própria à vida cotidiana:

Se essa situação é considerada sob o ponto de vista da vivência receptiva, chega-se ao problema, já antes retratado, da transformação do homem inteiro em homem inteiramente orientado à universalidade de um meio homogêneo. $\mathrm{O}$ conteúdo humano dessa transformaçáo pode ser formulado dizendo-se que o homem se afasta do contexto imediato e mediato da vida, - relativamente, como veremos em seguida - se desprende dele para orientar-se temporal e exclusivamente à contemplação de um concreto 
aspecto vital que redesenha o mundo como totalidade intensiva das determinaçóes decisivas que se oferecem numa certa perspectiva. (LUKÁCS, 1972, p. 495).

A catarse opera uma mudança momentânea na relação entre a consciência individual e o mundo, fazendo com que o indivíduo veja o mundo de uma maneira diferente daquela própria ao pragmatismo e ao imediatismo da vida cotidiana. Por meio dessa momentânea suspensão da vida cotidiana, a arte exerce um efeito formativo sobre o indivíduo, efeito esse que terá suas repercussóes na vida do indivíduo, mas tais repercussóes não ocorrem de maneira direta e imediata, havendo entre elas e a catarse estética uma complexa trama de mediaçóes que torna impossível definir a priori as consequências, para a vida de um determinado indivíduo, do processo de recepção de uma determinada obra de arte. A compreensão do caráter formativo da obra de arte requer, segundo a perspectiva lukacsiana, a superação de duas concepçóes igualmente equivocadas: a do caráter absolutamente desinteressado da vivência artística e a do utilitarismo dessa vivência. Mas a correta consideração do papel social e educativo da arte não é algo que tenha surgido com marxismo, ela existe desde a Antiguidade:

As tendências vivas e progressistas na Estética, como a orientação da Antiguidade, a da Ilustração, a dos democratas revolucionários russos, etc., sempre puseram em primeiro plano o grande papel social da arte [...] Essa posição reconhece o poder das vivências estéticas, que influem intensamente no homem e podem inclusive transformá-lo; neste sentido rechaça por antecipação toda teoria que procure isolar o estético da vida social. Porém a estética antiga não contempla essa função social como uma prestação de serviços a tal ou qual finalidade atual e concreta, mas sim descobre sua significação no fato de que um determinado exercício de determinadas artes é parte das forças formadoras da vida humana e, portanto, da vida social; que a arte é capaz de influir nos homens nas direçóes de efeito promotor ou inibidor da formação de determinados tipos humanos. Por isso Aristóteles distingue entre o efeito musical que se limita a produzir o gozo sensorial e o outro efeito da 
música - sem dúvida intimamente entrelaçado com o primeiro - que é ético e pelo qual essa arte "influi no caráter e na alma”. (LUKÁCS, 1972, p. 499).

Não seria essa uma questão igualmente importante para a reflexão sobre o significado social da educação escolar e das matérias escolares? É recorrente, na história dos debates pedagógicos, a controvérsia entre duas posiçôes acerca da educação escolar: uma é a de que tal educação deveria estar diretamente a serviço das necessidades postas imediatamente pela prática social do aluno, ao passo que a outra é a de que a educação escolar deveria ser democrática e, para tanto, seus conteúdos deveriam ter um caráter desinteressado e neutro. Essa segunda posição atualmente é encontrada com muito menos frequência do que a primeira, mas não se pode dizer que ela tenha desaparecido por inteiro do pensamento e da prática educacionais. Aliás, ela necessariamente continua existindo no discurso dos defensores da primeira posição, pois, para defendê-la, eles utilizam-se do argumento de que a alternativa à educação academicista seria necessariamente uma escola vinculada às demandas postas pela prática cotidiana. Uma versão, por assim dizer "de esquerda", dessa posição seria aquela que considera justificáveis apenas conteúdos escolares que produzissem um efeito imediatamente visível no sentido da formação de um pensamento crítico por parte do aluno. Essas duas posiçóes opostas apresentam em comum a ausência de uma reflexão sobre as mediaçóes entre o processo educativo escolar e a prática social. E a análise de Lukács leva em conta a natureza essencialmente mediada das relaçôes entre a vivência estética e a prática cotidiana dos indivíduos. Não seria frutífero buscar nessa análise contribuiçôes para a reflexão sobre as mediações que devem ser consideradas no processo de seleção dos conhecimentos que devam compor o currículo escolar? $\mathrm{O}$ mesmo pode ser dito em relação aos métodos e processos de ensino e aprendizagem. Talvez possam ser extraídas, dessa análise filosófica da vivência estética, particularmente no que se refere às relações dialéticas entre conteúdo e forma e entre aparência e essência, ideias férteis para a reflexão sobre as relaçóes entre processo e produto na atividade educativa.

Existem aspectos nos quais a vivência estética se assemelha à atividade educativa como, por exemplo, o fato de que nenhuma delas transforma diretamente a sociedade, nem mesmo transforma diretamente a vida do indivíduo. Ambas, porém, podem exercer uma influência decisiva, seja na 
transformação da sociedade, seja na da vida do indivíduo. Como afirma Heller (1994, p. 203):

A arte por si só não pode humanizar a vida; porém quando se tem a necessidade de humanizar a própria vida e dos demais também em outros níveis - o nível político, moral etc. - a arte proporciona um parâmetro e cumpre a função de apoio sentimental e intelectual para operar a transformação.

Mas as analogias entre a vivência estética e a atividade educativa têm seus limites. A atividade educativa requer a mediação do professor na relação entre o aluno e o conhecimento científico, o artístico e o filosófico. $\mathrm{O}$ ensino é indispensável em se tratando da relação entre o indivíduo e os conteúdos escolares. O professor age deliberadamente visando a alcançar objetivos previamente estabelecidos em termos da aquisição de conhecimentos pelos alunos. Além disso, o professor está em contato direto com o aluno. Esse contato direto não existe, por exemplo, no caso da relação entre o autor de um romance e os seus leitores. A relação do leitor é com o romance, isto é, com a obra e somente por meio dela é que ele se relaciona com o autor. Por sua vez, na maioria dos casos, o professor não produziu o conhecimento que ensina a seus alunos; o que o professor produz é o ensino desse conhecimento. A sociedade exige resultados positivos do trabalho do professor em termos do rendimento da aprendizagem realizada por seus alunos. No caso do escritor, basta que existam pessoas interessadas em ler seu livro, não há nenhuma exigência em termos do quanto elas assimilem por meio da leitura. Também o leitor não é avaliado em termos dos "resultados" de sua leitura. A situação muda quando o romance passa a ser usado na educação escolar. Sem deixar de ser uma obra de arte, o romance passa também a ter a função de objeto pedagógico, e, como tal, é avaliada sua adequação ou inadequação aos objetivos educacionais, às circunstâncias nas quais transcorre a atividade educativa, às características do aluno etc. Também é avaliado o trabalho que o professor realiza com esse romance e a aprendizagem dos alunos em termos de sua formação como leitores. Evidencia-se, assim, a necessidade de clareza quanto às diferenças significativas entre a vivência estética e a atividade educativa escolar, evitando-se, dessa forma, transposiçóes imediatas e ilegítimas da reflexão de cunho estético realizada por Lukács e por Vigotski para a reflexão no terreno de uma teoria da educação escolar. A mesma 
cautela seria necessária se a pesquisa procurasse contribuiçóes para uma teoria educacional em reflexóes de natureza epistemológica sobre a natureza do conhecimento científico. Transposiçóes imediatas de formulaçóes no terreno da teoria do conhecimento científico para a teoria pedagógica são passíveis de equívocos tão graves quanto aqueles que possam resultar da transposição direta das formulaçóes no campo da teoria estética para o campo da teoria pedagógica. Mas é inegável que as reflexões epistemológicas são importantes para a teoria educacional, assim como o são as reflexóes estéticas, éticas e ontológicas. Especialmente quando seus autores são pensadores com o brilhantismo de Lukács e de Vigotski, que uniam a intensidade do compromisso político-ideológico a um domínio profundo e extensivo não só dos clássicos do marxismo, como também da obra dos grandes nomes da história da filosofia, das ciências e das artes.

\section{Notas}

1 Este texto foi elaborado a partir de uma apresentação realização na sessão especial "Educação e Estética na (nova) sociabilidade" realizada no dia 6/10/2009 (REUNIÃO..., 2009) e incorporou também partes de um trabalho que foi apresentado no GT de Filosofia da Educação (REUNIÃO..., 2008).

2 Essa pesquisa conta com bolsa de produtividade em pesquisa do CNPq para o período de março de 2008 a fevereiro de 2011.

3 Como ficará evidente na sequência do artigo, o conceito de catarse em Vigotski e em Lukács tem um significado muito distinto daquele com que esse conceito é empregado pela Psicanálise.

\section{Referências}

HELLER, A. Sociología de la vida cotidiana. 4. ed. Barcelona: Península, 1994.

LUKÁCS, G. Introdução a uma estética marxista. 2. ed. Rio de Janeiro: Civilização Brasileira, 1970.

. Estética: la peculiaridad de lo estético. 2. ed. Barcelona: Grijalbo,

1972. v. 2. 
. Sociología de la Literatura. 4. ed. Barcelona: Grijalbo, 1989.

MARX, K. O capital: crítica da economia política. São Paulo: Victor Civita, 1983. v. 1.

- Elementos fundamentales para la crítica de la economía política (grundrisse). 15. ed. México (DF): Siglo Veintiuno, 1987. . Manuscritos econômico-filosóficos. São Paulo: Boitempo, 2004. ; ENGELS, Friedrich. Sobre literatura e arte. 3. ed. São Paulo, Global, 1986. ; __. A ideologia alemã. São Paulo: Boitempo, 2007. REUNIÁO ANUAL DA ASSOCIAÇÃO NACIONAL DE PÓSGRADUAÇÃO E PESQUISA EM EDUCAÇÃO, 31., 2008, Caxambu, M. G. Anais... Caxambu, M.G, 2008.

REUNIÃO ANUAL DA ASSOCIAÇÃO NACIONAL DE PÓSGRADUAÇÃO E PESQUISA EM EDUCAÇÃO, 32., 2009, Caxambu, M.G. Anais... Caxambu, M.G, 2009.

VIGOTSKI, L. S. Psicologia da arte. São Paulo: Martins Fontes, 1998. 


\section{Art and Education against the generalized fetishism in contemporary sociability}

\section{Abstract}

This article conducts a philosophical reflection on the contribution that art and education can offer to the process of overcoming the generalized fetishism in contemporary sociability. Marx's thesis that sociability in capitalist society is characterized by the universality of exchange value as a mediation of social relations is used. The article defends the position that contemporary sociability, despite differences with that of the 19th century, have not only not overcome the universality of exchange value, as they have - to the contrary - deepened it, making fetishism a social phenomenon that embraces all dimensions of human life today. The article also finds support in the analyses conducted by Vigotsky and Lukács of the relationships between individuals and works of art to defend the thesis that school education should have as a permanent goal the overcoming of the alienated forms of consciousness that prevail in daily life in capitalist society in this early 21 st century.

Key words: Art and education. Fetishism. Sociability. Alienation.

\section{Arte y Educación contra el fetichismo generalizado en la sociabilidad contemporánea}

\section{Resumen}

El presente artículo desarrolla una reflexión filosófica sobre la contribución que el arte y la educación pueden dar al proceso de superación del fetichismo generalizado en la sociabilidad contemporánea. En el primer ítem es retomada la tesis de Marx que destaca que la sociabilidad en la sociedad capitalista se caracteriza por la universalidad del valor de cambio como mediación en las relaciones sociales. El artículo defiende la posición de que la sociabilidad contemporánea en que pesen sus diferencias en relación al siglo XIX, no solamente no superó la universalidad del valor de cambio, sino que, al contrario, lo profundizó, tornando al fetichismo en un fenómeno social que abarca todas las dimensiones de la vida humana en la actualidad. En el segundo ítem el artículo auxiliase en las análisis realizadas por Vigotski y Lukács sobre las relaciones entre los individuos y las obras de arte para defender la tesis de que a educación escolar debe tener como meta permanente la superación de las formas alienadas de consciencia que prevalecen en la vida cotidiana de la sociedad capitalista de este inicio del siglo XXI.

Palabras clave: Arte e Educación. Fetichismo. Sociabilidad. Alienación. 


\section{Newton Duarte}

Universidade Estadual Paulista Júlio de Mesquita Filho Faculdade de Ciências e Letras de Araraquara

Departamento de Psicologia da Educação

Rodovia Araraquara - Jaú km 1 - Bairro dos Machados

CEP:14800-901 - Araraquara, SP

Caixa-Postal: 174

Telefone: (16) 3301-6210

URL da Homepage: www.fclar.unesp.br 